\title{
Albanian Legal Framework on Education and Education as Part of the Country Development
}

\author{
Mimoza Mehilli \\ PhD candidate UET, Justice Faculty, Profile of the Civil Rights \\ Email:mehilli.mimoza@gmail.com
}

\section{Doi:10.5901/jesr.2016.v6n2p49}

\begin{abstract}
Changes in social and political relations of the 90's came as a necessity for the change and reform of education in Albania. These changes primarily had to be done in the field of legislation, as well as in high school, university education and graduate education. For 50 years pre- university education in each part of the curriculum claimed only its achievements and development of socialism in the country. Difficulty was in the legal reform on which this education was based. It was very difficult to change the Albanian mentality for the schools to operate under in new laws and structure. The first change came in 1995 with the Law Nr. 7952 dated 21/06/1995 "For Pre- University Education", which changed again in 1998 the Law Nr.8387, dated 30/07/1998. These laws adapted much better the education system with new political and social conditions which Albania was going through at the time. Achievements in Albanian education, however, are not in the same level as the other EU countries, but they are a beginning to bring change in the systems of university, undergraduate, and graduate education and also the scientific research in the level of the developed countries. The education was free before the 90's but it was directed only by the Marxist ideas adapted to the level of the bolshevism profile, which made this education a closed and oriented type. This form of education was the first thing that needed to be changed and reformed. The right to get educated is a fundamental human right, part of the Albanian Constitution and also part of the European Human Rights Council; every person has this right regardless of gender, beliefs, economical status and religious belief.
\end{abstract}

Keywords: pre-university education, the right education, education Law, the education system, scientific research.

\section{Introduction}

The field of education as the other areas of social and cultural aspects in Albania up to the 90' was based on rigid laws, making the school a closed institution leaded from Marxist ideas copied from the other communism countries. After the 90' this situation required a very detailed reform which would change the Albanian education system.

It was very difficult to change an education system without firstly changing the laws where this system was based. Actually, this phenomenon happened at the time, the curriculum was really hard to change and as a result the entire teaching process was hard to change too. The education system in Albania after the 90' was constituted from: 8 years of required elementary education, high school (general and professional), university, graduate studies.

The elementary and high school education up to 1994-1995 was under the old communism law, but in 1995 the Popular Assembly approved the law 7952 dated.21.06.1995 "for the pre-university education system" which changed again in 1998 and in 2007, and lately in 2012 as the law number 69.

The university education was a four year degree stated by the law up to 2007, some areas had a five year degree, without any main change after the 90'. The only change was the way of applying in universities; all the students had to undergo state Matura exams. In 2007 the Assembly approved the law for "University education" based on Bologna Card, which brought the need to deeply reform the system and changing it to a 3+2 system, the best way for Albanian universities.

The scientific research and graduate studies were and continue to be the weakest link in Albanian education system. According to the actual laws, everybody that has a university degree has the right to study furthermore, but in reality this is only a privilege for a certain part of the population.

\section{Goals and Objectives}

The main goal of this paper is to intruduce the problems in the educational albanian system after 1990's under e reformed law specter. 


\title{
3. Objectives
}

1- A detailed presentation of the law specter for the preuniversity, university and undergraduate education in albania.

2- Through a legal analyses we will present the reasons why these laws and their frequent changes cause confusion in the education development in Albania

3- We will suggest the way the education system should be in Albania in order to compete with the EU countries where we want to take part.

\section{Pre-university Education}

After the independence in 1944 the education in Albania was in its lowest level of all, where 85\% of the population couldn't read or write. The main ambition of the Hoxha government was to literally pull the population out of the deep ignorance. So, in 1946 the government of that time presented the education reforms and the Popular Assembly approved the laws on: "Required elementary education" and the "Education Reform". This reform had started in the Teachers' Congress in 1944 in Korca, which set the bases for the war spirit and popular revolution.

In 1948-1049 as a result of this reform the elementary schools increased with $73 \%$. This brought the need to state which classes were required, up to 1951-1952 the elementary education was required by law, in the cities and villages. In 1955 the elementary education changed to seven years of schooling. On 24.12.1968 the law of "The new education system" was approved and on 20.02.1970 the popular Assembly approved the law "On the education system" which gradually changed the seven year elementary education to eight year elementary education, all required by law. Up to the end of 1980' Albania achieved a full education system based on communism ideology in each part of the curricula.

The constitution of 1976 would better describe the ideology of the Albanian education. In the $32^{\text {nd }}$ article it stated:

\begin{abstract}
"The state develops a wide ideological and cultural movement for the communism education of the workers, in order to form the new man. The state especially takes care for the development and complete education of the youth with the ideas of communism and socialism". The decentralized flow of the Albanian education in all its aspects would be presented in 33rd article which stated: "The education in Albanian Republic is organized and lead from the state, is open for everybody and is free; it is based on the Marxist Leninism approach and combines education with practical work and physical and army education. The education follows the best tradition of the national Albanian school and it is not religious."
\end{abstract}

The achievement of the Albanian education, even though based on communism ideology, during the period of 1990-1995 had a significant downfall, which came from the emigration of the population and the demographic changes. A high number of children dropped out of school and started working as the result of the economic crises.

As a result of the need to bring the education in its high levels again, in 1995 was approved the law number 7952 dated 21.6.1995 which later changed into the law number 8387, dated 30.7.1998. This law in its first atricle very clearly states the main idea the Albanian education is based: "Education in the Albanian Republic is a national priority. It is realized in concordance to the sanctioned ideas of this legislation, based on the achievement of our national schooling and it is achieved according to the agreement and international treaties ratified from the Albanian Republic. Education respects the rights of children and adults sanctioned in these documents".

This article also shows the direction that education would take not only based in our tradition, but also based on international agreements and treaties. The third article states:" The citizens of the Albanian republic have the equal rights to get an education stated by this law, regardless of social and economic status, language, religion, political ideas, health status...."

This shows that education is a right that everybody has in Albanian republic regardless of the changes made.

If we make a detailed analyses of the pre-university law we will notice that the aspect of the this law include the requirement of the international agreement ratified from Albania, especially the education rights of the children according to article 26 of the Universal Declaration of the Human Rights, articles 27-28 of the Convention for the Children Rights, the articles 13-14 of the "International treaty for the economic, social and cultural rights", article 18 of the "International treaty for the protection of the fundamental human rights", article 7 of the international Convent "For the elimination of all forms of racial discrimination", article 10 of the Convention "For the elimination of all forms of women discrimination", articles 2-5 of the Convent "For the war against discrimination in the education area". So this includes such a wide legal aspect of education protection. 
In 2007 the albanian education system changes from the eight year to nine year sytem. In 2012 was approved the law number 69 "For the pre-university education" which changed the role of the actors who are part of the school, making the parents have a very important role in the Bord of decision making. But, even though the law is very clear on this matter, most of th etime it is not followed.

\section{University Education}

In the city of Tirana in 1946 was opened the Higher Institute with a two year system, aimed to fullfill the needs of the country, which had just come out of the war, for educated teachers. In 1957 in Shkodra was opened another Higher Education Insitute and this continued with other ones all over Albania, in Girokastra, in Elbasan too. These institutes operated on a three year system up to 1987 and after that changed to a four year system, also changing to universitites and not Institutions. They functioned according to the soviet model.

After the $90^{\prime}$ this part of the ducation needed to be reorganized too. The problem was not only finding the model where this education would be based, but also the formation of the appropriate legal system to regulate the course of this education. The experiences that the albanian teachers received in western countries made it possible the creation of a clear idea of the phase where the Higher Education stood and where it should be.

The main step had be done in the development of a literature to create skilled specialists to fullfill the needs of the country. The way students entered the university studies was the same with the one before the 90'. But during 19922003 we notice a raise of the desire to study university education and this brought the opening of some Institutions of the Higher Educaions in order to gace the flow of the students.

The high increase of the needs to study university education brought the opening of the first private university in 2003-2004. Today in Albania there are a lot of private universities, in higher numbers than the public ones. In 2007 was approved the law number 9741, dated 21.5.2007 which would change forever the system of university studies. The system would consist of three years of Bachelor studies and two years of professional or scientific master degree. The execution of this new system brought confusion in the study programs and in the received diplomas got at the end of the studies. This law started to be applied much later. The law for the Higher Education approved a few months earlier, even though had many objections from the group of interests, brings a new era in Higher Education giving more autonomy to the university. This indepedence will have more efect on the quality of the academic staff sel;ection and the quality of the majoring students.

Another new thing that this law brought is that the public and private universities would be called the same, indepedent public institutions of the university education (IALPP). These intitutions are public entities known as judicial individual. Both of them should fullfill some criteria in order to be IALPP. The forms of the study in universities are full time and part time. The part time studies may be offered in one or two years with professional character, programes of the second cycle as the professional Master and programs of the third cycle as executive Master.

A very undesirable thing about the Albanian education is the quality of the graduate studies and scientific research. Most of the students who finish universities want to study in variuos other countries, as in Albania it is almost impossible to follow graduate studies, and their quality is very low.

\section{Education and the Country Development}

The Great greek phylosopher Aristotle has said for the education: "The roots of education are very bitter, but the its fruit is very sweet". This statement is very true for Albania as the education system has gone through a very probelmatic transition road.

Albanian aspirations to be part of the European family are based in the closeness of the European Standards, as presented in the articles of the Treaty for the Association and Stabilization (April 1st 2009). One of the main aspects of the European Standards is the education which is very important in the increase of the economical and social development of the country. This goal is the guarantee of a national modern education system, which encourages the steady economic development, promotes the competition in the region and consolidates the civil awareness.

Through the education the society transmits from one generation to the other its best values. The lagal status for the education for all the levels is now complete. Everyday it is mentioned a detailed reform in education, but in fact this does not really happen, everything continues according to the interests and short vision, delaying the creation of a education system according to the European Standards. This model is very clear. The question is "Where does Albania take place?". The European countries make it very important for them the creation of a univeristy model within their 
country, but is this possible in Albania too? This can only be done if the laws are being followed and the right reform is being made. This process is really hard, but not impossible.

\section{Conclusion/Reccomandations}

a. Pre-university education as a major step of the general education and it is the basis for the model 6 elementary classes +3 middle school classes +3 high school classes in order to be more efficient and with high quality.

b. Through the high school and university studies we prepare students in order for them to be professionals in their field of study to fullfill the needs of the economy market.

c. Achieving the autonomy of the universities in their curricula selection and the teaching staff employment.

d. To better integrate the teaching process with scientific research based on practice than theory, making the teachers more qualified.

e. To help the best students to be an active part of the university and the scientific research. They are needed in our country.

f. To finance the teachers and students who do research in order to geve them the best opportunities for a qulified academic work.

\section{Abbreviations}

- $\mathrm{AL}$--- University Education

- AF -.- Elementary Education

- AMU- Lower high school education

- $\mathrm{AML}$ - Higher high school education

- IL - Higher institute

- ILP- Educational University

- IALPP- Indepedent Public Institutions of the University Education

- MAP Professional Master

- MAS- Master of Science

\section{References}

The constitution of the Republic of Albania 1976

The constitution of the Republic of Albania 1998

Law number 7952, dated 21.6.1995" For pre-university education " Law number 8387, dated 30.7.1998" For pre-university education " Law number 9741 , dated 21.5 .2007 " For university education " Agency of research, Technology and Inovation (v.2009) http://open.data.al/sq/lajme/lajm/lang/en/id/126/Zhvillimi----Arsimit-te-Larte-ne-periudhen-1991-2011\#sthash.J3niOMAw.dpuf http://sot.com.al/politike-intervista/artan-fuga-7-arsyet-pse-ligji-i-ri-p\%C3\%ABr-arsimin-e-lart\%C3\%AB-falimenton-dhefundos\#sthash.XDjHOltr.dpuf http://shqiptarja.com/aktualitet/2731/ligji-i-ri--si-ndryshon-arsimi-i-lart--nga-tarifat-tek-financimet-ligji-sot-n--kuvendpddo-e-bllokojm-305798.html\#sthash.U14dvA5k.dpuf 